\title{
Synthesis of stable phosphorus ylides from 3, 5-dimethylpyrazole and kinetic investigation of the reactions by UV spectrophotometry
}

\author{
Sayyed Mostafa Habibi Khorassani*, Malek Taher Maghsoodlou, Mahmoud Nassiri, \\ Mohammad Zakarianezhad, and Mahbobeh Fattahi \\ Department of Chemistry, The University of Sistan and Baluchestan , P. O. Box 98135-674, \\ Zahedan, Iran \\ E-mail:smhabibius@yahoo.com
}

\begin{abstract}
Stable crystalline phosphorus ylides were obtained in excellent yields from the 1:1:1 addition reactions between triphenylphosphine and dialkyl acetylenedicarboxylates, in the presence of a $\mathrm{NH}$-acid, such as 3,5-dimethylpyrazole. These stable ylides exist in solution as a mixture of two geometrical isomers as a result of restricted rotation around the carbon-carbon partial double bond resulting from conjugation of the ylide moiety with the adjacent carbonyl group. To determine the kinetic parameters of the reactions, they were monitored by UV spectrophotometery. The second order fits were drawn and the values of the second order rate constant $\left(\mathrm{k}_{2}\right)$ were calculated automatically using standard equations within the program. At the temperature range studied, the dependence of the second order rate constant $\left(\mathrm{Ln} \mathrm{k}_{2}\right)$ on reciprocal temperature was in good agreement with the Arrhenius equation. This provided the relevant plots to calculate the activation energy of all reactions. Furthermore, useful information was obtained from studies of the effect of solvent, structure of reactants (different alkyl groups within the dialkyl acetylenedicarboxylates) and also concentration of reactants on the rate of reactions. The proposed mechanism was confirmed according to the obtained results and steady state approximation and first step $\left(\mathrm{k}_{2}\right)$ of reaction was recognized as a rate-determining step on the basis of experimental data.
\end{abstract}

Keywords: Stable phosphorus ylides, kinetic parameters, NH-acid, UV spectrophotometry, triphenylphosphine

\section{Introduction}

Development of simple synthetic routes for widely used organic compounds from readily available reagents is one of the major tasks in organic chemistry. ${ }^{1}$ Phosphorus ylides are reactive systems, which take part in many valuable reactions in organic synthesis ${ }^{2-12}$ and are most often 
prepared by treatment of a phosphonium salt with a base. Most of the phosphonium salts are prepared from the reaction of a phosphine and an alkyl halide ${ }^{3-7}$ though they can be obtained also by Michael addition of phosphorus nucleophiles to activated olefins. ${ }^{2,3}$ Herein, we wish to describe an efficient synthetic route to, and kinetic study of, stable phosphorus ylides using triphenylphosphine, dialkyl acetylenedicarboxylates and a NH-acid such as 3,5dimethylpyrazole. As noted earlier, the 3,5-dimethylpyrazole moiety and its derivatives are widely used in the preparation of medicines. ${ }^{13}$ With respect to the importance of this purpose, the present work was undertaken for generation of stable phosphoranes. Accordingly, the reaction of triphenylphosphine $\mathbf{1}$ with dialkylacetylene dicarboxylates $\mathbf{2}$ (2a or $\mathbf{2 b}$ ) in the presence of a $\mathrm{NH}$-acid 3 led to the corresponding stable heterocyclic phosphorus ylides 4 (4a or 4b) in excellent yields (see Figure 1).

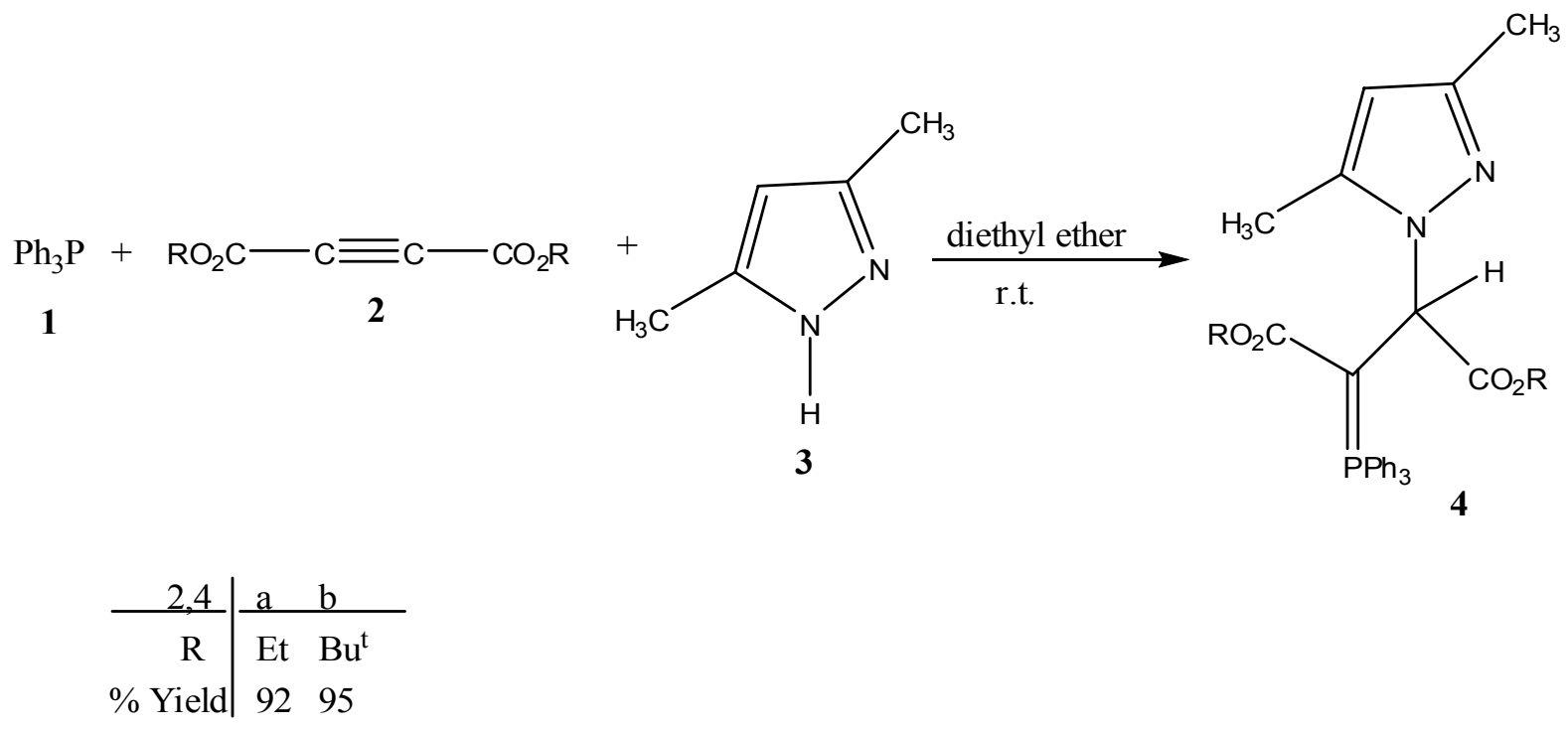

Figure 1..The reaction between triphenylphosphine 1, dialkyl acetylendicarboxylates $\mathbf{2}$ ( $\mathbf{2 a}$ or 2b) and 3,5-dimethylpyrazole 3 for generation of stable phosphorus ylides 4 (4a or $\mathbf{4 b}$ ).

\section{Results and Discussion}

The reactions of 3,5-dimethylpyrazole $\mathbf{3}$ with dialkyl acetylenedicarboxylates $\mathbf{2}$ in the presence of triphenylphosphine $\mathbf{1}$ were carried out in diethyl ether solvent at room temperature and were complete within a few hours. The ${ }^{1} \mathrm{H}$ and ${ }^{13} \mathrm{C}$ NMR spectra of the crude products indicated clearly the formation of stable phosphorus ylides $\mathbf{4}$. Any products other than $\mathbf{4}$ could not be detected by NMR spectroscopy. The structures of compounds $\mathbf{4 a , b}$ were deduced from their IR, ${ }^{1} \mathrm{H},{ }^{13} \mathrm{C}$ and ${ }^{31} \mathrm{P}$ NMR spectra. Their mass spectra displayed molecular ion peaks at appropriate $\mathrm{m} / \mathrm{z}$ values and initial fragmentations involved the loss of parts or the complete side chains and scission of the heterocyclic ring system. The ${ }^{1} \mathrm{H},{ }^{13} \mathrm{C}$, and ${ }^{31} \mathrm{P}$ NMR spectra of ylides $4 \mathbf{a}$ are 
consistent with the presence of two isomers. The ylide moiety of these compounds is strongly conjugated with the adjacent carbonyl group and rotation around the partial double bond in $(E)-4$ and $(Z)-4$ geometrical isomers is slow on the NMR timescale at ambient temperature (see Figure 2). Selected ${ }^{1} \mathrm{H},{ }^{13} \mathrm{C}$, and ${ }^{31} \mathrm{P}$ NMR chemical shifts and coupling constants in compound $\mathbf{4 b}$ and the major $(\mathrm{M})$ and minor $(\mathrm{m})$ geometrical isomers of compound $\mathbf{4 a}$ are shown in Table $\mathbf{1}$. As can be seen, only one geometrical isomer was observed for $\mathbf{4 b}$, presumably, because of the bulky tert-butyl groups.
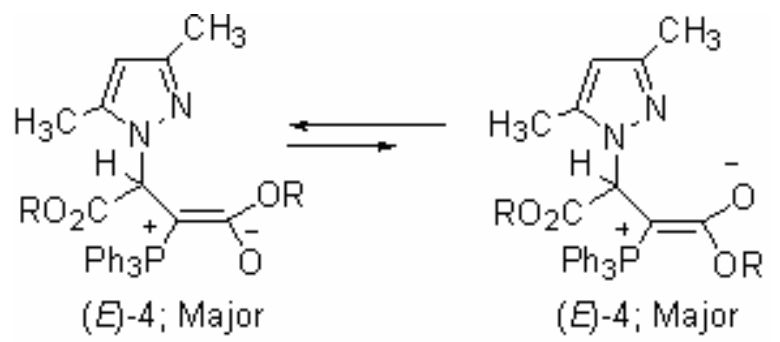

Figure 2. Two geometrical isomers (Major and Minor) of stable phosphorus ylide (4a).

The ${ }^{1} \mathrm{H}$ NMR spectra (500 MHz) of compound 4a displayed four triplets (at $\delta=0.42$ and $1.19,{ }^{3} \mathrm{~J}_{\mathrm{HH}}=7.2 \mathrm{~Hz}, \delta=1.24$ and $1.31,{ }^{3} \mathrm{~J}_{\mathrm{HH}}=7.1 \mathrm{~Hz}$, ) arising from methyl protons along with signals for methine protons at $\delta=5.45$ and $5.14 \mathrm{ppm}$, which appear as two doublets $\left({ }^{3} \mathrm{~J}_{\mathrm{PH}}=19.4\right.$ $\mathrm{Hz})$ and $\left({ }^{3} \mathrm{~J}_{\mathrm{PH}}=19.1 \mathrm{~Hz}\right)$, respectively, for the major and minor geometrical isomers. The ${ }^{13} \mathrm{C}$ NMR spectrum of $\mathbf{4 a}$ exhibited 34 distinct resonances that are in a good agreement with the mixture of two rotational isomers. Although the presence of the ${ }^{31} \mathrm{P}$ nucleus complicates both the ${ }^{1} \mathrm{H}$ and ${ }^{13} \mathrm{C}$ NMR spectra of $\mathbf{4 a}$, it helps in assignment of the signals by long-range couplings with the ${ }^{1} \mathrm{H}$ and ${ }^{13} \mathrm{C}$ nuclei (see Experimental section). The ${ }^{1} \mathrm{H}$ and ${ }^{13} \mathrm{C}$ NMR spectra of $\mathbf{4 b}$ are similar to those of $\mathbf{4 a}$, except for the ester groups, which exhibited characteristic resonances with appropriate chemical shifts (see Experimental section). The ${ }^{1} \mathrm{H}$ and ${ }^{13} \mathrm{C} \mathrm{NMR}$ spectral data for compounds $\mathbf{4 a , b}$ are consistent with the geometrical isomers. The structural assignments made on the basis of the ${ }^{1} \mathrm{H}$ and ${ }^{13} \mathrm{C}$ NMR spectra of compounds $\mathbf{4 a}, \mathbf{b}$ were supported by the IR spectra. The carbonyl region of the spectra exhibited two distinct absorption bands for each compound (see Experimental section). Of special interest is the ester absorption at $1726-1631 \mathrm{~cm}^{-}$ ${ }^{1}$ for these compounds. Conjugation with the negative charge appears to be a plausible factor in the reduction of the wave numbers of the carbonyl absorption bands. 
Table 1. Selected ${ }^{1} \mathrm{H},{ }^{13} \mathrm{C}$, and ${ }^{31} \mathrm{P}$ NMR chemical shifts ( $\delta$ in ppm) and coupling constants $(J$ in $\mathrm{Hz}$ ) for $\mathrm{H}-2, \mathrm{OR}, \mathrm{CO}_{2} \mathrm{R}, \mathrm{C}-2$, and $\mathrm{C}-3$, in the major $(\mathrm{M})$ and minor $(\mathrm{m})$ diastereoisomers of compounds $\mathbf{4 a , b}$

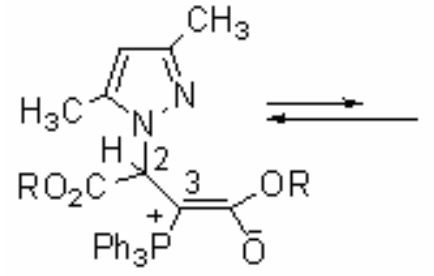

(E)-4; Major

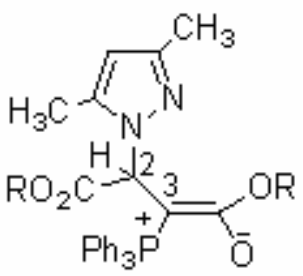

(Z)-4; Minor

${ }^{1} \mathrm{H}$ NMR spectroscopy data $\quad{ }^{13} \mathrm{C}$ NMR data

\begin{tabular}{cccccccc}
\hline Compound & $\begin{array}{c}\text { Isomer } \\
(\%)\end{array}$ & $\mathrm{H}-2\left({ }^{3} J_{\mathrm{PH}}\right)$ & $\mathrm{OR}$ & $\mathrm{CO}_{2} \mathrm{R}$ & $\mathrm{C}-2\left({ }^{2} J_{\mathrm{PC}}\right)$ & $\mathrm{C}-3\left({ }^{1} J_{\mathrm{PC}}\right)$ & $\begin{array}{c}{ }^{31} \mathrm{P} \\
\mathrm{NMR}\end{array}$ \\
\hline $4 \mathrm{a}$ & $\mathrm{M}(76)$ & $5.45(19.4)$ & 3.71 & 3.95 & $62.42(13.3)$ & $41.57(128.7)$ & 23.07 \\
$4 \mathrm{a}$ & $\mathrm{m}(24)$ & $5.14(19.1)$ & 4.01 & 4.25 & $61.94(14.2)$ & $41.84(132.1)$ & 23.55 \\
$4 \mathrm{~b}$ & $\mathrm{M}(67)$ & $5.01(18.4)$ & 0.94 & 1.49 & $62.29(15.5)$ & $40.89(126.4)$ & 23.89 \\
\hline
\end{tabular}

On the basis of the well established chemistry of trivalent phosphorus nucleophiles, ${ }^{2-6}$ it is reasonable to assume that phosphorus ylide $\mathbf{4}$ results from the initial addition of triphenylphosphine to the acetylenic ester $\mathbf{2}$ (rate constant $\mathrm{k}_{2}$ ) and subsequent protonation of the 1:1 adduct by the $\mathrm{NH}$-acid $\mathbf{3}$ ( rate constant $\mathrm{k}_{3}$ ) to form phosphoranes $\mathbf{4}$ (rate constant $\mathrm{k}_{4}$ ) (see Figure 3).

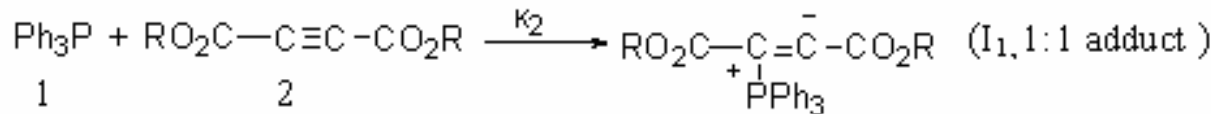

$$
\begin{aligned}
& \mathrm{RO}_{2} \mathrm{C}-\mathrm{C}=\overline{\mathrm{C}}-\mathrm{CO}_{2} \mathrm{R} \stackrel{\mathrm{k}_{-2}}{\mathrm{PPh}}-\mathrm{Ph}_{3} \mathrm{P}+\mathrm{RO}_{2} \mathrm{C}-\mathrm{C} \equiv \mathrm{C}-\mathrm{CO}_{2} \mathrm{R}
\end{aligned}
$$

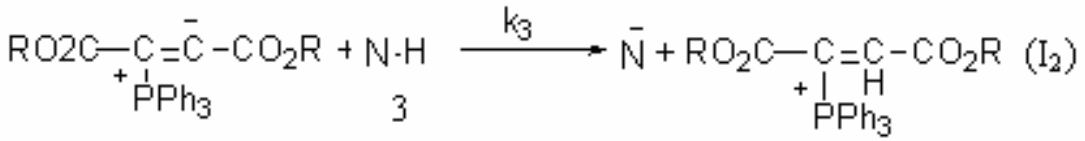

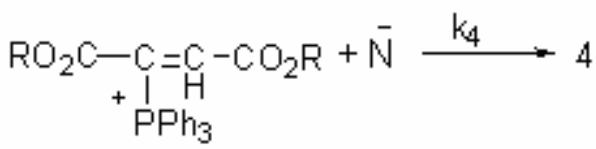

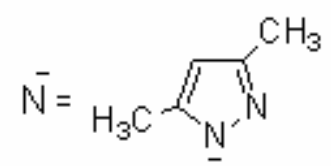

Figure 3. Proposed mechanism for the reaction between 1, $2(\mathbf{2 a}$ or $\mathbf{2 b})$ and 3 for generation of phosphorus ylides 4 (4a or $\mathbf{4 b})$. 


\section{Experimental Section}

General Procedures. Melting points, IR and UV spectra of all compounds were measured on an Electrothermal 9100 apparatus, a Shimadzu IR-460 spectrometer and a Cary UV/VIS spectrophotometer model Bio-300 with a $10 \mathrm{~mm}$ light-path black quartz spectrophotometer cell, respectively. In addition, the ${ }^{1} \mathrm{H},{ }^{13} \mathrm{C}$, and ${ }^{31} \mathrm{P}$ NMR spectra were obtained from a BRUKER DRX-300 AVANCE instrument with $\mathrm{CDCl}_{3}$ as solvent at 300.1, 121.4, and $75.5 \mathrm{MHz}$, respectively. The mass spectra were recorded on a Shimadzu QP 1100 EX mass spectrometer operating at an ionization potential of $70 \mathrm{eV}$. Elemental analysis for $\mathrm{C}, \mathrm{H}$ and $\mathrm{N}$ were performed using a Heraeus CHM-O-Rapid analyzer. Dialkyl acetylene dicarboxylates, triphenylphosphine and 3,5-dimethylpyrazole were purchased from Fluka, (Buchs, Switzerland) and used without further purification.

\section{Preparation of diethyl 2-(3,5-dimethylpyrazole-1-yl)-3-(triphenylphosphoranylidene)- butanedioate (4a). General procedure}

To a magnetically stirred solution of triphenylphosphine $(0.26 \mathrm{~g}, 1 \mathrm{mmol})$ and 3,5dimethylpyrazole $(0.95 \mathrm{~g}$ or $1 \mathrm{mmol})$ in $10 \mathrm{~mL}$ of diethyl ether was added, dropwise, a mixture of diethyl acetylenedicarboxylate $(1 \mathrm{mmol})$ in $4 \mathrm{~mL}$ of diethyl ether at $-5{ }^{\circ} \mathrm{C}$ over $10 \mathrm{~min}$. After approximately 3 hours stirring at room temperature, the product was filtered and recrystallized from diethyl ether. White powder. Mp 143-145 ${ }^{\circ} \mathrm{C}$, yield $0.49 \mathrm{~g}, 92 \%$. IR $(\mathrm{KBr})\left(v_{\max }, \mathrm{cm}^{-1}\right)$ : 1727 and $1631(\mathrm{C}=\mathrm{O})$. MS ( $/ \mathrm{z}$, \%): $528(\mathrm{M}, 3), 455\left(\mathrm{M}-\mathrm{CO}_{2} \mathrm{Et}, 55\right), 433$ (M-heterocycl, 17), $287\left(\mathrm{M}-\mathrm{PPh}_{2}\right.$ and 2Et, 17), $262\left(\mathrm{PPh}_{3}, 76\right), 183\left(\mathrm{PPh}_{2}, 79\right), 108(\mathrm{PPh}, 57)$. Anal. Calcd. For $\mathrm{C}_{31} \mathrm{H}_{33} \mathrm{~N}_{2} \mathrm{O}_{4} \mathrm{P}(528)$ : C, 71.08; H, 6.31; N, 5.25\%. Found: C, 70.45; H, 6.25; N, 5.30\%.

Major isomer of 4a. $(76 \%):{ }^{1} \mathrm{H}$ NMR $\left(300.1 \mathrm{MHz}, \mathrm{CDCl}_{3}\right): \delta_{\mathrm{H}} 0.42$ and $1.19\left(6 \mathrm{H}, 2 \mathrm{t},{ }^{3} \mathrm{~J}_{\mathrm{HH}}=7.2\right.$ $\left.\mathrm{Hz}, 2 \mathrm{O}-\mathrm{C}-\mathrm{CH}_{3}\right), 2.02$ and $2.21\left(2 \mathrm{~s}, 2 \mathrm{CH}_{3}\right), 3.71$ and $3.95\left(4 \mathrm{H}, 2 \mathrm{~m}, 2 \mathrm{ABX}_{3}\right.$ system, 2O-CH $\left.\mathrm{H}_{2}-\mathrm{C}\right)$, $5.45\left(1 \mathrm{H}, \mathrm{d},{ }^{3} \mathrm{~J}_{\mathrm{HP}}=19.4 \mathrm{~Hz}, \mathrm{P}-\mathrm{C}-\mathrm{CH}\right), 5.66\left(1 \mathrm{H}, \mathrm{H}_{3} \mathrm{C}-\mathrm{C}=\mathrm{CH}\right), 7.42-7.73\left(15 \mathrm{H}, \mathrm{m}, 3 \mathrm{C}_{6} \mathrm{H}_{5}\right) .{ }^{13} \mathrm{C}$ $\operatorname{NMR}\left(75.5 \mathrm{MHz}, \mathrm{CDCl}_{3}\right): \delta_{\mathrm{C}} 10.93$ and $13.67\left(2 \mathrm{CH}_{3}, \mathrm{C}_{5} \mathrm{H}_{7} \mathrm{~N}_{2}\right), 14.07$ and $14.14\left(2 \mathrm{~s}, 2 \mathrm{O}-\mathrm{C}-\mathrm{CH}_{3}\right)$, $41.57\left(\mathrm{~d},{ }^{1} \mathrm{~J}_{\mathrm{PC}}=128.7 \mathrm{~Hz}, \mathrm{P}=C\right), 57.66$ and $60.69\left(2 \mathrm{~s}, 2 \mathrm{O}-\mathrm{CH}_{2}-\mathrm{C}\right), 62.42\left(\mathrm{~d},{ }^{2} \mathrm{~J}_{\mathrm{PC}}=13.3 \mathrm{~Hz}, \mathrm{P}-\mathrm{C}-\right.$ $\mathrm{CH}), 104.82\left(1 \mathrm{C}, \mathrm{C}_{5} \mathrm{H}_{7} \mathrm{~N}_{2}\right), 127.33\left(\mathrm{~d},{ }^{1} \mathrm{~J}_{\mathrm{PC}}=91.9 \mathrm{~Hz}, \mathrm{C}_{\mathrm{ipso}}\right), 128.27\left(\mathrm{~d},{ }^{3} \mathrm{~J}_{\mathrm{PC}}=12.1 \mathrm{~Hz}, \mathrm{C}_{\text {meta }}\right)$, $131.73\left(\mathrm{C}_{\text {para }}\right), 134.09\left(\mathrm{~d},{ }^{2} \mathrm{~J}_{\mathrm{PC}}=9.9 \mathrm{~Hz}, \mathrm{C}_{\text {ortho }}\right), 138.75$ and $145.23\left(2 \mathrm{C}, \mathrm{C}_{5} \mathrm{H}_{7} \mathrm{~N}_{2}\right), 169.14\left(\mathrm{~d},{ }^{3} \mathrm{~J}_{\mathrm{PC}}=\right.$ $12.2 \mathrm{~Hz}, \mathrm{C}=\mathrm{O}$ ester $), 171.38\left(\mathrm{~d},{ }^{2} \mathrm{~J}_{\mathrm{PC}}=10.9 \mathrm{~Hz}, \mathrm{P}-\mathrm{C}=C\right) .{ }^{31} \mathrm{P}$ NMR $\left(121.5 \mathrm{MHz}, \mathrm{CDCl}_{3}\right): \delta_{\mathrm{P}}$ 23.07 $\left(\mathrm{Ph}_{3} \mathrm{P}^{+}-\mathrm{C}\right)$.

Minor isomer of 4a. (24 \%): ${ }^{1} \mathrm{H}$ NMR (300.1 MHz, $\left.\mathrm{CDCl}_{3}\right)$ : $\delta_{\mathrm{H}} 1.24$ and $1.31\left(6 \mathrm{H}, 2 \mathrm{t},{ }^{3} \mathrm{~J}_{\mathrm{HH}}=7.1\right.$ $\left.\mathrm{Hz}, 2 \mathrm{O}-\mathrm{C}-\mathrm{CH}_{3}\right), 2.02$ and $2.08\left(2 \mathrm{~s}, 2 \mathrm{CH}_{3}\right), 4.01$ and $4.25\left(4 \mathrm{H}, 2 \mathrm{~m}, 2 \mathrm{ABX}_{3}\right.$ system, $\left.2 \mathrm{O}-\mathrm{CH}_{2}-\mathrm{C}\right)$, $5.14\left(1 \mathrm{H}, \mathrm{d},{ }^{3} \mathrm{~J}_{\mathrm{HP}}=19.1 \mathrm{~Hz}, \mathrm{P}-\mathrm{C}-\mathrm{CH}\right), 5.69\left(1 \mathrm{H}, \mathrm{H}_{3} \mathrm{C}-\mathrm{C}=\mathrm{C} H\right), 7.42-7.73\left(15 \mathrm{H}, \mathrm{m}, 3 \mathrm{C}_{6} \mathrm{H}_{5}\right) .{ }^{13} \mathrm{C}$ NMR $\left(75.5 \mathrm{MHz}, \mathrm{CDCl}_{3}\right): \delta_{\mathrm{C}} 10.97$ and $13.54\left(2 \mathrm{CH}_{3}, \mathrm{C}_{5} \mathrm{H}_{7} \mathrm{~N}_{2}\right), 13.83$ and $13.92(2 \mathrm{~s}, 2 \mathrm{O}-\mathrm{C}-$ $\left.\mathrm{CH}_{3}\right), 41.84\left(\mathrm{~d},{ }^{1} \mathrm{~J}_{\mathrm{PC}}=132.1 \mathrm{~Hz}, \mathrm{P}=\mathrm{C}\right), 58.42$ and $60.69\left(2 \mathrm{~s}, 2 \mathrm{O}-\mathrm{CH}_{2}-\mathrm{C}\right), 61.94\left(\mathrm{~d},{ }^{2} \mathrm{~J}_{\mathrm{PC}}=14.2 \mathrm{~Hz}\right.$, $\mathrm{P}-\mathrm{C}-\mathrm{CH}), 104.99\left(1 \mathrm{C}, \mathrm{C}_{5} \mathrm{H}_{7} \mathrm{~N}_{2}\right), 126.62\left(\mathrm{~d},{ }^{1} \mathrm{~J}_{\mathrm{PC}}=92.0 \mathrm{~Hz}, \mathrm{C}_{\mathrm{ipso}}\right), 128.50\left(\mathrm{~d},{ }^{3} \mathrm{~J}_{\mathrm{PC}}=11.2 \mathrm{~Hz}, \mathrm{C}_{\text {meta }}\right)$, $131.76\left(\mathrm{C}_{\text {para }}\right), 133.58\left(\mathrm{~d},{ }^{2} \mathrm{~J}_{\mathrm{PC}}=10.1 \mathrm{~Hz}, \mathrm{C}_{\text {ortho }}\right), 138.72$ and $145.34\left(2 \mathrm{C}, \mathrm{C}_{5} \mathrm{H}_{7} \mathrm{~N}_{2}\right), 170.36\left(\mathrm{~d},{ }^{3} \mathrm{~J}_{\mathrm{PC}}=\right.$ 
$12.7 \mathrm{~Hz}, \mathrm{C}=\mathrm{O}$ ester), $171.44\left(\mathrm{~d},{ }^{2} \mathrm{~J}_{\mathrm{PC}}=11.3 \mathrm{~Hz}, \mathrm{P}-\mathrm{C}=\mathrm{C}\right) .{ }^{31} \mathrm{P} \mathrm{NMR}\left(121.5 \mathrm{MHz}, \mathrm{CDCl}_{3}\right): \delta_{\mathrm{P}} 23.55$ $\left(\mathrm{Ph}_{3} \mathrm{P}^{+}-\mathrm{C}\right)$.

Di-tert-buthyl 2-(3,5-dimethylpyrazole -1-yl)-3-(triphenylphosphoranylidene)-butanedioate (4b). White powder, m.p 157-159 ${ }^{\circ} \mathrm{C}, 0.55 \mathrm{~g}$, yield $95 \%$. IR $\left(v_{\text {rnax }}, \mathrm{cm}^{-1}\right): 1726$ and 1638 $(\mathrm{C}=\mathrm{O}) . \mathrm{Mz}(\mathrm{m} / \mathrm{z}, \%): 483\left(\mathrm{M}-\mathrm{CO}_{2} \mathrm{CMe}_{3}, 17\right), 382\left(\mathrm{M}-2 \mathrm{CO}_{2} \mathrm{CMe}_{3} 17\right), 287\left(\mathrm{M}-\mathrm{PPh}_{2}\right.$ and $2 \mathrm{CMe}_{3}$, 34), 262( $\left.\mathrm{PPh}_{3}, 79\right), 183\left(\mathrm{PPh}_{2}, 79\right), 108(\mathrm{PPh}, 55)$; Anal. Aacld** for $\mathrm{C}_{35} \mathrm{H}_{41} \mathrm{~N}_{2} \mathrm{O}_{4} \mathrm{P}(584)$ : $\mathrm{C}$, 72.53; H, 6.97; N, 4.83, Found: C, 71.92; H, 7.02; N, 4.79. ${ }^{1} \mathrm{H}$ NMR $\left(300.1 \mathrm{MHz}, \mathrm{CDCl}_{3}\right): \delta_{\mathrm{H}}$ 0.94 and $1.49\left(18 \mathrm{H}, 2 \mathrm{~s}, 2 \mathrm{CMe} e_{3}\right), 2.03$ and $2.20\left(2 \mathrm{CH}_{3}, \mathrm{C}_{5} \mathrm{H}_{7} \mathrm{~N}_{2}\right), 5.01\left(1 \mathrm{H}, \mathrm{d},{ }^{3} \mathrm{~J}_{\mathrm{HP}}=18.4 \mathrm{~Hz}, \mathrm{P}-\mathrm{C}-\right.$ $\mathrm{CH}), 5.67\left(1 \mathrm{H}, \mathrm{H}_{3} \mathrm{C}-\mathrm{C}=\mathrm{CH}\right), 7.41-7.69\left(15 \mathrm{H}, \mathrm{m}, 3 \mathrm{C}_{6} \mathrm{H}_{5}\right) .{ }^{13} \mathrm{C} \mathrm{NMR}\left(75.5 \mathrm{MHz}, \mathrm{CDCl}_{3}\right): \delta_{\mathrm{C}} 11.32$ and $13.61\left(2 \mathrm{~s}, 2 \mathrm{CH}_{3}, \mathrm{C}_{5} \mathrm{H}_{7} \mathrm{~N}_{2}\right), 28.17$ and $28.43(2 \mathrm{~s}, 2 \mathrm{OCMe}), 40.89\left(\mathrm{~d},{ }^{1} \mathrm{~J}_{\mathrm{PC}}=126.4 \mathrm{~Hz}, \mathrm{P}=\mathrm{C}\right)$, 64.29(d, $\left.{ }^{2} \mathrm{~J}_{\mathrm{PC}}=15.5 \mathrm{~Hz}, \mathrm{P}-\mathrm{C}-\mathrm{CH}\right), 77.89$ and $80.27(2 \mathrm{~s}, 2 \mathrm{OCMe}), 105.22\left(1 \mathrm{C}, \mathrm{C}_{5} \mathrm{H}_{7} \mathrm{~N}_{2}\right)$, $\left(127.84\left(\mathrm{~d},{ }^{1} \mathrm{~J}_{\mathrm{PC}}=91.6 \mathrm{~Hz}, \mathrm{C}_{\mathrm{ipso}}\right), 128.31\left(\mathrm{~d},{ }^{3} \mathrm{~J}_{\mathrm{PC}}=12.2 \mathrm{~Hz}, \mathrm{C}_{\text {meta }}\right), 131.70\left(\mathrm{C}_{\mathrm{para}}\right), 133.99\left(\mathrm{~d},{ }^{2} \mathrm{~J}_{\mathrm{PC}}=\right.\right.$ $\left.9.7 \mathrm{~Hz}, \mathrm{C}_{\text {ortho }}\right), 139.04$ and $144.96\left(2 \mathrm{C}, \mathrm{C}_{5} \mathrm{H}_{7} \mathrm{~N}_{2}\right), 167.85\left(\mathrm{~d},{ }^{3} \mathrm{~J}_{\mathrm{PC}}=12.2 \mathrm{~Hz}, \mathrm{C}=\mathrm{O}\right.$ ester $), 170.06(\mathrm{~d}$, $\left.{ }^{2} \mathrm{~J}_{\mathrm{PC}}=13.8 \mathrm{~Hz}, \mathrm{P}-\mathrm{C}=C\right) .{ }^{31} \mathrm{P}$ NMR $\left(121.5 \mathrm{MHz}, \mathrm{CDCl}_{3}\right): \delta_{\mathrm{P}} 23.89\left(\mathrm{Ph}_{3} \mathrm{P}^{+}-\mathrm{C}\right)$.

\section{Kinetic studies}

The synthetic reactions between triphenylphosphine 1, dialkyl acetylenedicarboxylates 2 and $\mathrm{CH}, \mathrm{SH}$ or $\mathrm{NH}$-acids have been reported earlier ${ }^{14-32}$ but the kinetic study of these reactions has not been investigated yet. Herein, we wish to describe a kinetic investigation of the current synthesis. Numerous kinetic investigations over a large area of different reactions have been reported previously using UV analysis. ${ }^{35-46}$ In order to gain further insight into the reaction mechanism, a kinetic study of the reactions was undertaken by the UV spectrophotometric technique. First, it was necessary to find the appropriate wavelength in order to follow the kinetic study of the reaction. For this purpose, in the first experiment, a $3 \times 10^{-3} \mathrm{M}$ solution of compounds $\mathbf{1 , 2} \mathbf{2 b}$ and $\mathbf{3}$ was prepared in 1,4-dioxane as solvent. An approximately $3 \mathrm{~mL}$ aliquot from each reactant was pipetted into a $10 \mathrm{~mm}$ light path quartz spectrophotometer cell and the relevant spectra were recorded over the wavelength range 190-400 nm. Figures 4, 5 and $\mathbf{6}$ show the ultraviolet spectra of compounds $\mathbf{1}, \mathbf{2 b}$ and $\mathbf{3}$, respectively. In a second experiment, a $1 \mathrm{~mL}$ aliquot from the $3 \times 10^{-3} \mathrm{M}$ solutions of each compound $\mathbf{1}$ and $\mathbf{3}$ was pipetted first into a quartz spectrophotometer cell (as there is no reaction between them). Later, a $1 \mathrm{~mL}$ aliquot of the $3 \times 10^{-}$ ${ }^{3} \mathrm{M}$ solution of reactant $\mathbf{2} \mathbf{b}$ was added to the mixture and the reaction monitored by recording scans of the entire spectrum every 13 min over the whole reaction time at ambient temperature. The ultraviolet spectra shown in Figure 7 are typical. From these, the appropriate wavelength was found to be $330 \mathrm{~nm}$ (corresponding mainly to product $\mathbf{4 b}$ ) since at this wavelength, compounds $\mathbf{1}, \mathbf{2} \mathbf{b}$ and $\mathbf{3}$ have relatively no absorbance value. This, then, provided the opportunity to fully investigate the kinetics of the reaction between triphenylphosphine 1, di-tert-butyl acetylenedicarboxylate $\mathbf{2 b}$ and 3,5-dimethylpyrazole $\mathbf{3}$ at $330 \mathrm{~nm}$ in the presence of 1,4-dioxane as solvent. Since the spectrophotometer cell of the UV equipment had a $10 \mathrm{~mm}$ light-path cuvette, the UV/Vis spectra of compound $\mathbf{4 b}$ were measured over the concentration range $\left(2 \times 10^{-}\right.$ $\left.{ }^{4} \mathrm{M} \leq \mathrm{M}_{4 \mathrm{~b}} \leq 10^{-3} \mathrm{M}\right)$ to check for a linear relationship between absorbance values and 
concentrations. With a suitable concentration range and wavelength identified, the following procedure was employed.

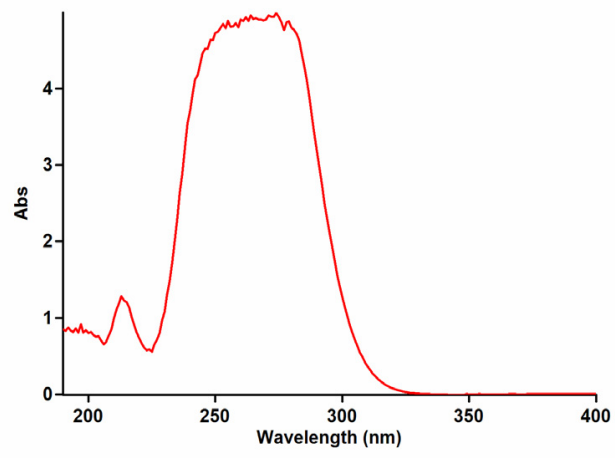

Figure 4. The UV spectrum of $10^{-3} \mathrm{M}$ triphenyl-phosphine $\mathbf{1}$ in 1,4-dioxane.

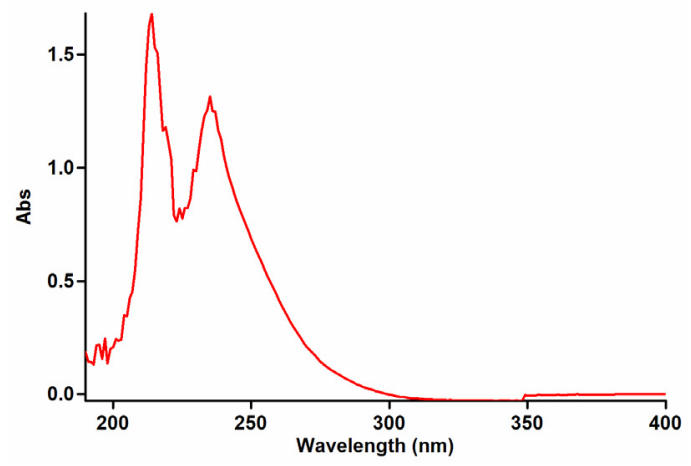

Figure 5. The UV spectrum of $10^{-3} \mathrm{M}$ di-tert-butyl -acetylenedicarboxylate $\mathbf{2 b}$ in 1,4-dioxane.

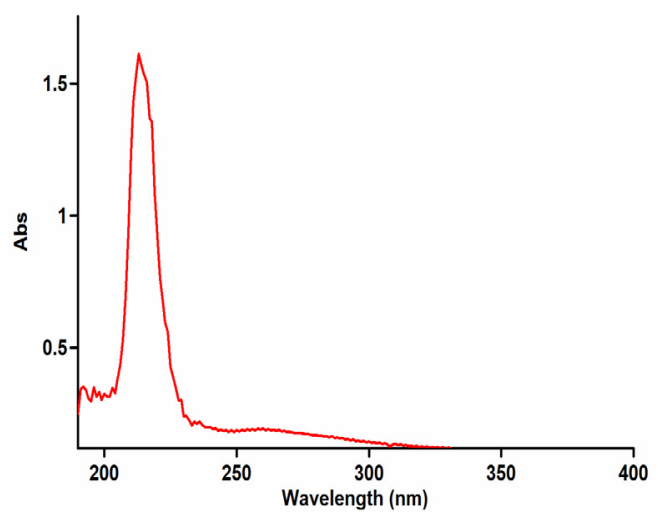

Figure 6. The UV spectrum of $10^{-3} \mathrm{M} 3,5$-dimethylpyrazole 3 in 1,4-dioxane. 


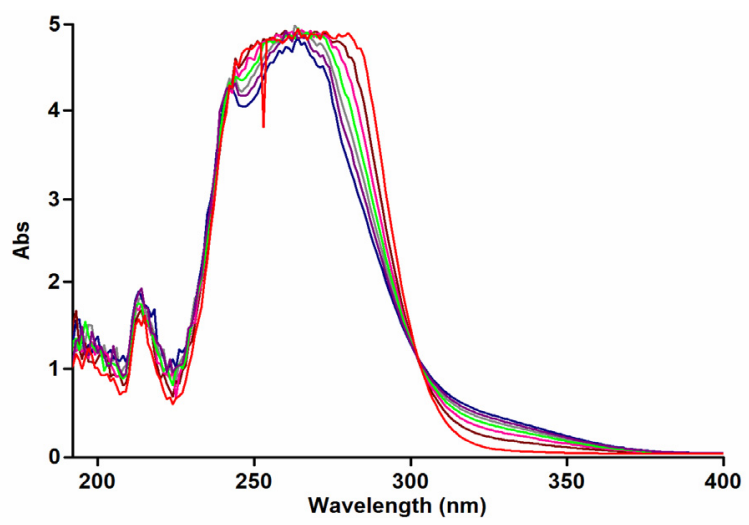

Figure 7. The UV spectra of the reaction between $\mathbf{1}, \mathbf{2 b}$ and $\mathbf{3}$ with $3 \times 10^{-3} \mathrm{M}$ concentration of each compound as reaction proceeds in 1, 4-dioxane with10 mm light-path cell.

For each kinetic experiment, first a $1 \mathrm{~mL}$ aliquot from each freshly made $3 \times 10^{-3} \mathrm{M}$ solution of compounds 1 and 3 in 1, 4-dioxane was pipetted into a quartz cell, and then a $1 \mathrm{~mL}$ aliquot of the $3 \times 10^{-3} \mathrm{M}$ solution of reactant $\mathbf{2} \mathbf{b}$ was added to the mixture, keeping the temperature at $15.0^{\circ} \mathrm{C}$. The reaction kinetics were followed by plotting UV absorbance against time. Figure 8 shows the absorbance change versus time for the 1:1:1 addition reaction between compounds $\mathbf{1}, \mathbf{2} \mathbf{b}$ and $\mathbf{3}$ at $15.0^{\circ} \mathrm{C}$. The infinity absorbance $\left(\mathrm{A}_{\infty}\right)$, that is the absorbance at reaction completion, can be obtained from Figure 8 at $\mathrm{t}=395 \mathrm{~min}$. With respect to this value, zero, first or second curve fitting could be drawn automatically for the reaction by the software ${ }^{47}$ associated with the UV instrument. Using the original experimental absorbance versus time data provided a second order fit curve (full line) that fits exactly the experimental curve (dotted line) as shown in Figure 9. Thus, the reaction between triphenylphosphine $\mathbf{1}$, di-tert-butyl acetylenedicarboxylate $\mathbf{2 b}$ and 3,5-dimethylpyrazole 3 follows second-order kinetics. The second-order rate constant $\left(\mathrm{k}_{2}\right)$ is then automatically calculated using a standard equation ${ }^{37}$ within the program at $15.0^{\circ} \mathrm{C}$. It is reported in Table 2. Further kinetic studies were carried out using the same concentration of each reactant in a series of experiments with concentrations of $5 \times 10^{-3} \mathrm{M}$ and $7 \times 10^{-3} \mathrm{M}$, respectively. As expected, the second order rate constant was independent of concentration and its value was the same as in the previous experiment. In addition, the overall order of reaction was also 2.

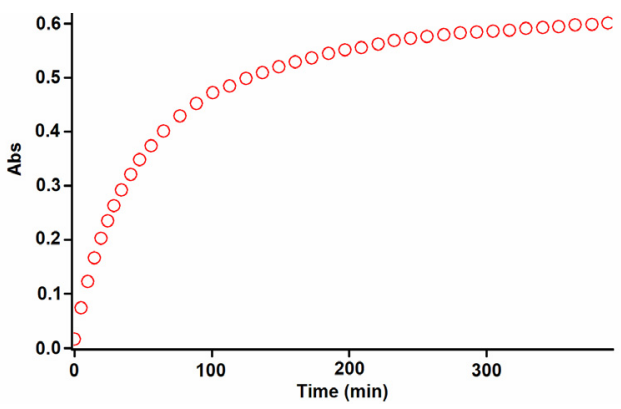

Figure 8. The experimental absorbance changes (dotted line) against time at $330 \mathrm{~nm}$ for the reaction between compounds $\mathbf{1}, \mathbf{2 b}$ and $\mathbf{3}$ at $15^{\circ} \mathrm{C}$. 


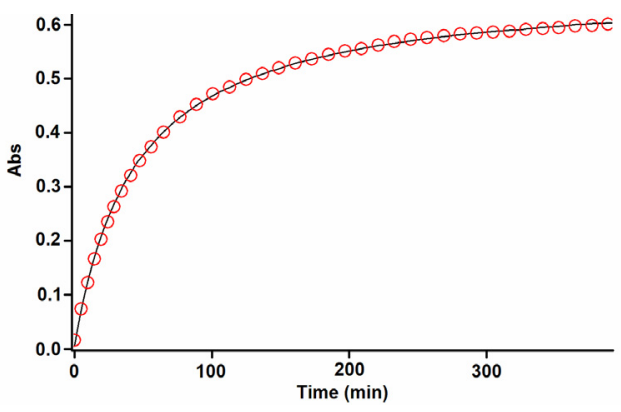

Figure 9. Second order fit curve (full line) accompanied by the original experimental curve (dotted line) for the reaction between compounds $\mathbf{1 ,} \mathbf{2 b}$ and $\mathbf{3}$ at $330 \mathrm{~nm}$ and $15.0^{\circ} \mathrm{C}$ in $1,4-$ dioxane.

\section{Effect of solvents and temperature}

To determine the effect of change in temperature and solvent environment on the rate of reaction, it was elected to perform various experiments at different temperatures and solvent polarities, but otherwise under the same conditions as for the previous experiment. For this purpose, ethyl acetate and 1,2-dichloroethane, with dielectric constants of 6 and 10, respectively, were chosen as suitable solvents since they not only dissolved all compounds but also did not react with them. The effects of solvents and temperature on the rate constant are given in Table 2.

Table 2. The values of overall second order rate constant for the reaction between $\mathbf{1 , 2} \mathbf{2 b}$ and $\mathbf{3}$ in the presence of solvents such as 1,4-dioxane and 1,2-dichloroethane at all temperatures investigated

\begin{tabular}{cccccc}
\hline & & \multicolumn{4}{c}{$\mathrm{k}_{2} \cdot \mathrm{M}^{-1} \cdot \mathrm{min}^{-1}$} \\
\cline { 3 - 6 } Solvent & $\varepsilon$ & $15.0^{\circ} \mathrm{C}$ & $20.0^{\circ} \mathrm{C}$ & $25.0^{\circ} \mathrm{C}$ & $30.0^{\circ} \mathrm{C}$ \\
\hline 1,4-dioxane & 2 & 47.6 & 60.1 & 75.3 & 96.4 \\
ethyl acetate & 6 & 62.5 & 78.2 & 96.4 & 121.3 \\
1,2-dichloroethane & 10 & 81.8 & 98.5 & 115.2 & 141.0 \\
\hline
\end{tabular}

The results show that the rate of reaction in each solvent was increased at higher temperature. In addition, the rate of reaction between $\mathbf{1}, \mathbf{2 b}$ and $\mathbf{3}$ was accelerated in a higher dielectric constant environment (1,2-dichloroethane) in comparison with a lower dielectric constant environment (1,4-dioxane) at all temperatures investigated. In the temperature range studied, the dependence of the second-order rate constant $\left(\mathrm{Ln} \mathrm{k}_{2}\right)$ of the reactions on reciprocal temperature is consistent with the Arrhenius equation, giving activation energies of reaction between $\mathbf{1}, \mathbf{2 b}$ and $3(26.4 \mathrm{~kJ} / \mathrm{mole})$ from the slope of Figure. 


\section{Effect of concentration}

To determine reaction order with respect to triphenylphosphine $\mathbf{1}$ and dialkyl acetylenedicarboxylate 2 (2b), in a series of separate experiments, all kinetic studies were carried out in the presence of excess 3 . Under this condition, the rate equation may therefore be expressed as: rate $=k_{\text {obs }}[1]^{\alpha}[2]^{\beta} \quad k_{o b s}=k_{2}[3]^{\gamma} \quad$ or $\quad \operatorname{Ln} k_{o b s}=\operatorname{Ln} k_{2}+\gamma \operatorname{Ln}[3]$

In this case $\left(3 \times 10^{-2} \mathrm{M}\right.$ of 3 instead of $\left.3 \times 10^{-3} \mathrm{M}\right)$ using the original experimental absorbance versus time data provides a second order fit curve (full line) against time at $330 \mathrm{~nm}$ which exactly fits the experimental curve. The value of the rate constant was the same as that obtained from the previous experiment $\left(3 \times 10^{-3} \mathrm{M}\right)$. Repetition of the experiments with $5 \times 10^{-2} \mathrm{M}$ and $7 \times 10^{-}$

${ }^{2} \mathrm{M}$ concentrations of 3 gave, separately, the same fit curve and rate constant. In fact, the experimental data indicated that the observed pseudo second order rate constant $\left(\mathrm{k}_{\mathrm{obs}}\right)$ was equal to the second order rate constant $\left(\mathrm{k}_{2}\right)$; this is possible when $\gamma$ is zero in equation (I). It appears, therefore, that the reaction is zero and second order with respect to 3 (NH-acid) and the sum of 1 and $2(\mathbf{2 b})(\alpha+\beta=2)$, respectively.

To determine the reaction order with respect to dialkyl acetylenedicarboxylate $\mathbf{2}(\mathbf{2 b})$, a separate experiment was performed in the presence of excess of $1 \quad\left(\right.$ rate $=k^{\prime}{ }_{\text {obs }}[3]^{\gamma}[2]^{\beta}$, $\mathrm{k}^{\prime}{ }_{\text {obs }}=\mathrm{k}_{2}[1]^{\alpha}$ (II)). The original experimental absorbance versus time data are shown in Figure 10. These data provide a pseudo first order fit curve at $330 \mathrm{~nm}$, which exactly fits the experimental curve (dotted line) as shown in Figure 11. As a result since $\gamma=0$ (as determined previously), it is reasonable to accept that the reaction is first order with respect to compound 2 (2b) $(\beta=1)$. Because the overall order of reaction is two $(\alpha+\beta+\gamma=2)$ it is obvious that $\alpha=1$ and the order of triphenylphosphine 1 must be equal to one. This observation was obtained also for reaction between 1, 2a and 3. Based on the above results, a simplified proposed reaction mechanism (Figure 3) is shown in Figure 12.

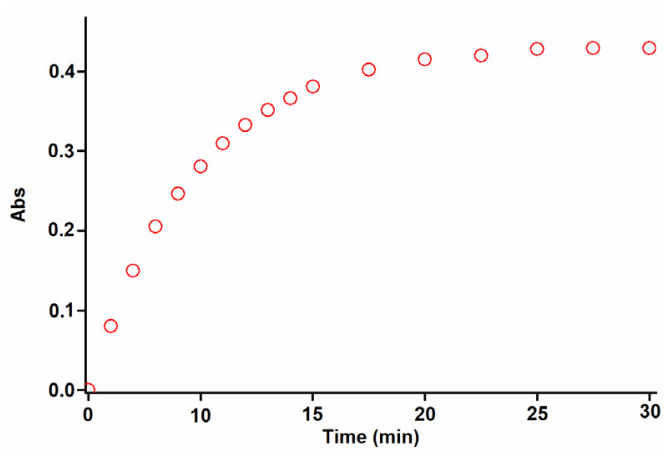

Figure 10. The experimental absorbance change versus time for the reaction between $\mathbf{2 b}$ and $\mathbf{3}$ in the presence of excess $1\left(10^{-2} \mathrm{M}\right)$ at $330 \mathrm{~nm}$ and $15.0^{\circ} \mathrm{C}$ in 1,4-dioxane. 


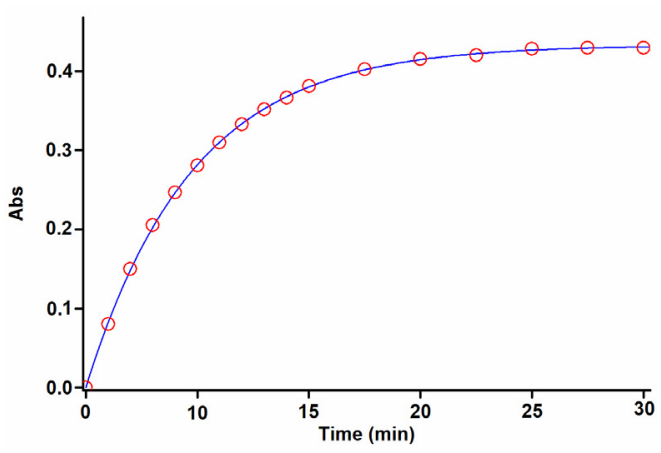

Figure 11. Pseudo first order fit curve (full line) for the reaction between $\mathbf{2 b}$ and $\mathbf{3}$ in the presence of excess $1\left(10^{-2} \mathrm{M}\right)$ at $330 \mathrm{~nm}$ and $15.0^{\circ} \mathrm{C}$ in 1,4-dioxane.

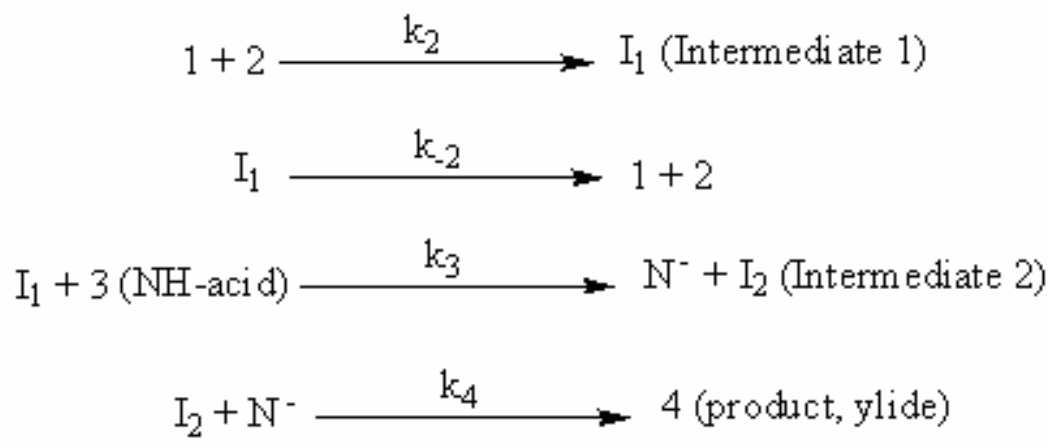

Figure 12. The simplified Scheme for the proposed reaction mechanism.

The experimental results indicate that the third step (rate constant $\mathrm{k}_{3}$ ) is possibly fast. In contrast, it may be assumed that the third step is the rate-determining step for the proposed mechanism. In this case the rate law can be expressed as follows:

rate $=k_{3}\left[I_{1}\right][3]$

The steady state assumption can be employed for $\left[\mathrm{I}_{1}\right]$ which generates the following equation, $\left[I_{1}\right]=\frac{k_{2}[1][2]}{k_{-2}+k_{3}[3]}$

The value of $\left[\mathrm{I}_{1}\right]$ can be replaced in equation (III) to obtain this equation: rate $=\frac{k_{2} k_{3}[1][2][3]}{k_{-2}+k_{3}[3]}$

Since it was assumed that $\mathrm{k}_{3}$ is relevant to the rate determining step, it is reasonable to make the following assumption : $\mathrm{k}_{-2}>>\mathrm{k}_{3}$ [3]

so the rate equation becomes: rate $=\frac{k_{2} k_{3}[1][2][3]}{k_{-2}}$

The final equation indicates that the overall reaction order is three, which is not compatible with the experimental overall order of reaction (= two). In addition, according to this equation 
the order of reaction with respect to 3,5-dimethylpyrazole 3 is one, whereas it was actually shown to be equal to zero. For this reason, it appeared that the third step is fast. If we assume that the fourth step (rate constant $\mathrm{k}_{4}$ ) is the rate-determining step for the proposed mechanism, in this case, there are two ionic species to consider in the rate-determining step, namely phosphonium ion $\left(\mathrm{I}_{2}\right)$ and pyrazole ion $\left(\mathrm{N}^{-}\right)$. The phosphonium and pyrazole ions, as we see in Figure $\mathbf{3}$, have full positive and negative charges and form very powerful ion-dipole bonds to the 1,2dichloroethane, the high dielectric constant solvent. However, the transition state for the reaction between the two ions carries a dispersed charge, which here is divided between the attacking pyrazole and the phosphonium ions. Bonding of solvent (1,2-dichloroethane) to this dispersed charge would be much weaker than to the concentrated charge of pyrazole and phosphonium ions. The solvent thus would stabilize the species ions more than it would the transition state, and therefore $E_{a}$ would be higher, slowing down the reaction. However, in practice, 1,2dichloroethane speeds up the reaction and, for this reason, the fourth step, which is independent of the change in the solvent medium, could not be the rate-determining step. Furthermore, the rate law of formation of the product (fourth step) for a proposed reaction mechanism with application of the steady state assumption can be expressed by: rate $=k_{4}\left[I_{2}\right]\left[N^{-}\right]$

By application of steady state for $\left[\mathrm{I}^{-}\right]$and $\left[\mathrm{N}^{-}\right]$, and replacement of their values in the above equation, the following equation is obtained: rate $=\frac{k_{2} k_{3}[1][2][3]}{k_{-2}+k_{3}[3]}$

This equation is independent of the rate constant for the fourth step $\left(\mathrm{k}_{4}\right)$ and shows why the fourth step would not be affected by a change in the solvent medium. In addition, it has been suggested earlier that the kinetics of ionic species' phenomena (e.g., the fourth step) are very fast. $^{48-49}$ If the first step (rate constant $\mathrm{k}_{2}$ ) were the rate determining step, in this case, two reactants (triphenylphosphine $\mathbf{1}$ and dialkyl acetylenedicarboxylate $\mathbf{2}$ ), as we see (Figure $\mathbf{3}$ ), have no charge and could not form strong ion-dipole bonds to the high dielectric constant solvent, 1,2dichloroethane. However, the transition state carries a dispersed charge which here is divided between the attacking 1 and $\mathbf{2}$ and, hence, bonding of solvent to this dispersed charge is much stronger than to the reactants, which lack charge. The solvent thus stabilizes the transition state more than it does the reactants and, therefore, $E_{a}$ is reduced which speeds up the reaction. Our experimental results show that the solvent with the higher dielectric constant exerts a power full effect on the rate of reaction (in fact, the first step has rate constant $\mathrm{k}_{2}$ in the proposed mechanism) but the opposite occurs with the solvent of lower dielectric constant (1,4-dioxane, see tables 2 and 3). The results of the current work (effects of solvent and concentration of compounds) have provided useful evidence for steps $1\left(\mathrm{k}_{2}\right), 3\left(\mathrm{k}_{3}\right)$ and $4\left(\mathrm{k}_{4}\right)$ of the reactions between triphenylphosphine $\mathbf{1}$, dialkyl acetylenedicarboxylate $\mathbf{2}(\mathbf{2 a}$ or $\mathbf{2 b})$ and 3,5dimethylpyrazole $\mathbf{3}$. Two steps involving 3 and 4 are not determining, although the discussed effects, taken altogether, are compatible with the first step $\left(\mathrm{k}_{2}\right)$ of the proposed mechanism and would allow it to be the rate-determining step. However, a good kinetic description of the experimental result using a mechanistic scheme based upon the steady state approximation is 
frequently taken as evidence of its validity. By application of this, the rate formation of product 4 from the reaction mechanism (Figure 12) is given by:

$\frac{d[4]}{d t}=\frac{d[y \text { lide }]}{d t}=$ rate $=k_{4}\left[I_{2}\right]\left[N^{-}\right]$

We can apply the steady-state approximation to $\left[\mathrm{I}_{1}\right]$ and $\left[\mathrm{I}_{2}\right]$;

$\frac{d\left[I_{1}\right]}{d t}=k_{2}[1][2]-k_{-2}\left[I_{1}\right]-k_{3}\left[I_{1}\right][3], \frac{d\left[I_{2}\right]}{d t}=k_{3}\left[I_{1}\right][3]-k_{4}\left[I_{2}\right]\left[N^{-}\right]$

To obtain a suitable expression for $\left[\mathrm{I}_{2}\right]$ to put into equation (V) we can assume that, after an initial brief period, the concentrations of $\left[\mathrm{I}_{1}\right]$ and $\left[\mathrm{I}_{2}\right]$ achieve a steady state with their rates of formation and rates of disappearance just balanced. Therefore, $\frac{d\left[I_{1}\right]}{d t}$ and $\frac{d\left[I_{2}\right]}{d t}$ are zero and we can obtain expressions for $\left[\mathrm{I}_{2}\right]$ and $\left[\mathrm{I}_{1}\right]$ as follows:

$$
\begin{aligned}
& \frac{d\left[I_{2}\right]}{d t}=0,\left[I_{2}\right]=\frac{k_{3}\left[I_{1}\right][3]}{k_{4}\left[N^{-}\right]} \\
& \frac{d\left[I_{1}\right]}{d t}=0,\left[I_{1}\right]=\frac{k_{2}[1][2]}{k_{-2}+k_{3}[3]}
\end{aligned}
$$

We can now replace $\left[\mathrm{I}_{1}\right]$ in the equation $(\mathrm{VI})$ to obtain this equation:

$\left[I_{2}\right]=\frac{k_{2} k_{3}[1][2][3]}{k_{4}\left[N^{-}\right]\left[k_{-2}+k_{3}[3]\right]}$

The value of $\left[\mathrm{I}_{2}\right]$ can be put into equation (V) to obtain the rate equation (VIII) for the proposed mechanism: rate $=\frac{k_{2} k_{3} k_{4}[1][2][3]\left[N^{-}\right]}{k_{4}\left[N^{-}\right]\left[k_{-2}+k_{3}[3]\right]}$ or rate $=\frac{k_{2} k_{3}[1][2][3]}{\left[k_{-2}+k_{3}[3]\right]}$

Since experimental data have indicated that steps $3\left(\mathrm{k}_{3}\right)$ and $4\left(\mathrm{k}_{4}\right)$ are fast but step $1\left(\mathrm{k}_{2}\right)$ is slow, it is therefore reasonable to make the following assumption: $\mathrm{k}_{3}[3]>>\mathrm{k}_{-2}$

so the rate equation becomes: $\quad$ rate $=k_{2}[1][2]$

This equation, which was obtained from a mechanistic scheme (shown in Figure 12) by applying the steady-state approximation, is compatible with the results obtained by UV spectrophotometry.

\section{Further kinetic investigations}

\section{Effect of structure of dialkyl acetylenedicarboxylates}

To confirm the above observations, further experiments were performed with diethyl acetylenedicarboxylate $\mathbf{2 a}$ under the same conditions used in the previous experiments. The values of the second-order rate constant $\left(\mathrm{k}_{2}\right)$ for the reaction between $\mathbf{1 ,} \mathbf{2 a}$ and $\mathbf{3}$ are reported in Table 3 for all solvents and temperatures investigated. The original experimental absorbance curves (dotted line) and the second order fit curve (full line), which exactly fits the experimental curve (dotted line), are shown in Figures 13 and 14 at $15.0^{\circ} \mathrm{C}$ and $330 \mathrm{~nm}$. 
Table 3. The values of overall second order rate constant for the reaction between 1, 2a and 3 in the presence of solvents such as, 1,4-dioxane and 1,2-dichloroethane at all temperatures investigated

\begin{tabular}{cccccc}
\hline & & \multicolumn{4}{c}{$\mathrm{k}_{2} \cdot \mathrm{M}^{-1} \cdot \mathrm{min}^{-1}$} \\
\cline { 3 - 6 } Solvent & $\varepsilon$ & $15.0^{\circ} \mathrm{C}$ & $20.0^{\circ} \mathrm{C}$ & $25.0^{\circ} \mathrm{C}$ & $30.0^{\circ} \mathrm{C}$ \\
\hline 1,4 -dioxane & 2 & 358.6 & 408.8 & 464.1 & 531.7 \\
ethyl acetate & 6 & 429.2 & 483.4 & 548.9 & 617.7 \\
1,2-dichloroethane & 10 & 488.5 & 551.2 & 618.0 & 692.3 \\
\hline
\end{tabular}

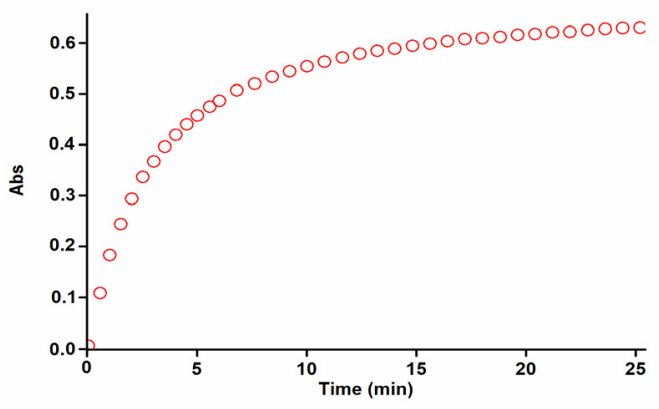

Figure 13. The experimental absorbance change (dotted line) versus time for the reaction between $\mathbf{1}, \mathbf{2 b}$ and $\mathbf{3}$ at $330 \mathrm{~nm}$ and $15.0^{\circ} \mathrm{C}$ in 1,4-dioxane.

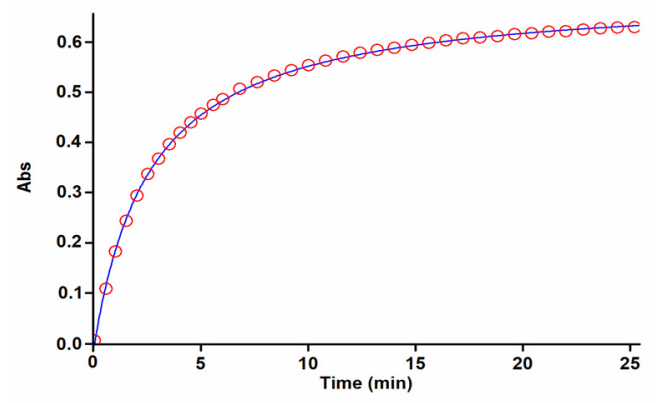

Figure 14. Second order fit curve (full line) accompanied by the original experimental curve (dotted line) for the reaction between $\mathbf{1}, \mathbf{2 b}$ and $\mathbf{3}$ at $330 \mathrm{~nm}$ and $15.0^{\circ} \mathrm{C}$ in 1,4-dioxane.

As can be seen from Table $\mathbf{3}$ the behavior of diethyl acetylenedicarboxylate 2a is the same as for di-tert-butyl acetylenedicarboxylate $\mathbf{2 b}$ (Table $\mathbf{2}$ ) with respect to the reaction with triphenylphosphine 1 and 3,5-dimethylpyrazole 3. The rate of the former reaction was also accelerated in a higher dielectric constant environment and with higher temperatures, however, this rate under the same conditions is approximately 5 to 6 times greater than for the reaction with di-tert-butyl acetylenedicarboxylate $\mathbf{2 b}$ (see Tables $\mathbf{2}$ and $\mathbf{3}$ ). It seems that both inductive 
and steric factors for the bulky alkyl groups in $\mathbf{2 b}$ tend to reduce the overall reaction rate (see equation IX). In the case of diethyl acetylenedicarboxylate $\mathbf{2 a}$, the lower steric and inductive effects of the diethyl groups exert a powerful effect on the rate of reaction.

\section{Conclusions}

Briefly, we have prepared novel phosphorus ylides using a one-pot reaction between triphenylphosphine and dialkyl acetylenedicarboxylates in the presence of a NH- acid such as 3,5 dimethylpyrazole. The present method carries the advantage that, not only is the reaction performed under neutral conditions, but also the substances can be mixed without any activation or modifications. The stable phosphorus ylides 4 (4a and $\mathbf{4 b}$ ) are potentially useful synthetic intermediates and the procedure described here may be acceptable for the preparation of phosphoranes with variable functionalities. In addition, kinetic investigations of these reactions were undertaken using UV spectrophotometry. The results can be summarized as follows; 1 . The appropriate wavelengths and concentrations were determined in order to follow the reaction kinetics. 2. The overall reaction order followed second-order kinetics and the reaction orders with respect to triphenylphosphine, dialkyl acetylenedicarboxylate and 3,5-dimethylpyrazole were one, one and zero, respectively. 3. The values of the second-order rate constants for all reactions were calculated automatically with respect to the standard equation using the software associated with the Cary-300 UV instrument. 4. The rates of all reactions were accelerated at high temperature. Under the same conditions, the activation energy of the reaction with di-tertbutyl acetylenedicarboxylate $\mathbf{2 b}(33.9 \mathrm{~kJ} / \mathrm{mol})$ was higher than that for the reaction with diethyl acetylenedicarboxylate $\mathbf{2 a}(18.9 \mathrm{~kJ} / \mathrm{mol})$ in 1,4-dioxane. 5. The rates of all reactions were increased in solvents of higher dielectric constant and this can be related to differences in stabilization by the solvent of the reactants and the activated complex in the transition state. 6 . Increased steric bulk in the alkyl groups of the dialkyl acetylenedicarboxylate, accompanied by the correspondingly greater inductive effect, reduced the overall reaction rate. 7. With respect to the experimental data, the first step of proposed mechanism was recognized as a rate determining step $\left(\mathrm{k}_{2}\right)$ and this was confirmed based upon the steady state approximation.

\section{Acknowledgements}

The authors sincerely thank the University of Sistan \& Baluchestan for providing financial support of this work. 


\section{References}

1. Laszo, P. Organic Reactions: Simplicity and Logic, Wiley: New York, 1995.

2. Johnson, A. W. Ylide Chemistry, Academic Press: London, 1966.

3. Cadogan, J. I. G. Organophosphorus Reagents in Organic Synthesis, Academic Press: New York, 1979.

4. Engel, R. Synthesis of Carbon-Phosphorus Bonds, CRC Press: Boca Raton, FL, 1988.

5. Hudson, H. R. The Chemistry of Organophosphorus Compounds, Primary, Secondary, and Tertiary Phosphates and Heterocyclic Organophosphorus (3) Compounds, Wiley: New York, 1990; p 382.

6. Corbridge, D. E. C. Phosphorus: An Outline of Chemistry, Biochemistry and Uses, Elsevier: Amsterdam, 1995.

7. Kolodiazhnyi, O. I. Russ. Chem. Rev. 1994, 66, 225.

8. Cherkasov, R. A.; Pudovic, M. A. Russ. Chem. Rev. 1994, 63, 1019.

9. Pietrusiewiz, K. M.; Zablocka, M. Chem. Rev. 1994, 94, 1375.

10. Maryanoff, B. E.; Rietz, A. B. Chem. Rev. 1989, 89, 863.

11. Nicolaou, K. C.; Harter, M. W.; Gunzner, J. L.; Nadin, A. Liebigs Ann. 1997, 1283.

12. Shen, Y. Acc. Chem, Res. 1998, 31, 584.

13. Gilchrist, T. L. Heterocyclic Chemistry, Wiley: NewYork, 1985.

14. Yavari, I.; Ramazani, A. Phosphorus, Sulphur, and Silicon 1997, 130, 73.

15. Yavari, I.; Esmaili, A.; Asghari, S.; Bijanzadeh, H. R. J. Chem. Res. 1999, 368.

16. Yavari, I.; Islami, M. R. J. Chem. Res. 1998, 166.

17. Yavari, I.; Bayat, M. Phosphorus, Sulphur, and Silicon 2002, 177, 2537.

18. Yavari, I.; Anary-Abbasinejad, M,; Alizadeh, A. Tetrahedron Lett. 2002, 4503.

19. Yavari, I.; Adib, M.; Hojabri, L. Tetrahedron 2002, 58, 7213.

20. Yavari, I.; Alizadeh, A.; Anary-Abbasinejad, M. Tetrahedron Lett. 2002, 9449.

21. Yavari, I.; Adib, M.; Jahani-Moghaddam, M. F.; Sayahi, M. H. Phosphorus, Sulphur, and Silicon 2002, 177, 545.

22. Yavari, I.; Islami, M. R.; Bijanzadeh, H. R. Tetrahedron 1999, 55, 5547

23. Yavari, I.; Hossein Mosslemin, M. Tetrahedron 1998, 54, 9169.

24. Yavara, I.; Ramazani, A. Synthetic Commun.1997, 27, 1385.

25. Yavara, I.; Esmaili, A. A. J. Chem. Res. 1998, 714.

26. Ramazani, A.; Shajari, N.; Gouranlou, F. Phosphorus, Sulphur, and Silicon 2001, 174, 223.

27. Yavara, I.; Alizadeh, A.; Anvary-Abbasnejad, M. Phosphorus, Sulphur and Silicon 2002, 177,81 .

28. Yavara, I.; Maghsoodlou, M.T.; Djahaniani, H.; Hazeri, N. J. Chem. Res. 1999, 216.

29. Maghsoodlou, M. T.; Hazeri, N.; Habibi khorassani, S. M.; Afshar, G. J. Chem. Res. 2005, 727.

30. Maghsoodlou, M. T.; Hazeri, N.; Habibi khorassani, S. M.; Nassiri, M. J. Sulfur Chemistry 2005, 261. 
31. Habibi khorassani, S. M.; Maghsoodlou, M. T.; Hazeri, N.; Nassiri, M.; Marandi, G. Phosphorus, Sulfur and Silicon 2006, 181, 567.

32. Maghsoodlou, M. T.; Habibi khorassani, S. M.; Hazeri, N.; Nassiri, M.; Kakaei, R. Phosphorus, Sulfur and Silicon 2006, 181, 553.

33. Maghsoodlou, M. T.; Habibi khorassani, S. M.; Rofouei, M. K.; Adhamdoust, S. R.; Nassiri, M. Arkivoc 2006, 145-151.

34. Maghsoodlou, M. T.; Hazeri, N.; Habibi khorassani, S. M.; Saghatforosh, L.; Rofouei, M. K.; Rexaie, M. Arkivoc 2006, 117.

35. Furtmuller, P. G.; Burner, U.; Regelsberger, G. J. Biochemistry 2000, 39, 15578.

36. Nielsen, O. J.; Sehsted, J.; Langer, S.; Ljungstrom, E.; Wangberg, I. J. Chem. Phys. Lett. 1995, 238, 359.

37. Langer, S.; Ljungstrom, E.; Ellemann, T.; Sehsted, J.; Nielsen, O. J. J. Chem. Phys. Lett. 1995, 240, 53.

38. Ragains, M. L.; Finlason-Pitts, B. J. Phys. Chem. A. 1997, 101, 1509.

39. Marti, N.; Hoa, G. H.; Kozelka, B. Inorganic Chemistry Commun. 1998, 1, 439.

40. Misiti, F.; Castagnola, M.; Zuppi, C.; Giardina, B. J. Biochem. 2001, 356, 799.

41. Carvalho, R. N.; Moura, L. S.; Rosa, P. T. V.; Angela, M. Supercritical Fluids 2005, 35 , 197.

42. Biver, T.; Secco, F.; Tine, M. R.; Ventorini, M. Inorganic Biochemistry 2004, 98, 33.

43. Andres, G, O.; Rossi, H. R. Arkivoc 2003, 127.

44. Zingaretti, L.; Boscatto, L.; Chiacchiera, M. S.; Silber, J. J. Arkivoc 2003, 189.

45. Rasia, M. R.; Vila, J. A. Arkivoc 2003, 507.

46. Chiang, Y.; Kresge, J.; Zhu, Y. Arkivoc 2001, 108.

47. Schwartz, L. M.; Gelb, R. I. Anal. Chem. 1978, 50, 1592.

48. Treglon, P. A.; Laurence G. S. J. Sci. Instrum. 1956, 42, 869.

49. Wolff, M. A. J. Chem. Instrum. 1976, 5, 5. 